\title{
Rational Stupidity
}

\section{Welles J*}

*Corresponding author: James Welles, Retired, P O Box 17 East Marion, NY 11939, USA, Tel: 954-531-5382; Email: JWelles103@aol.com

\section{Perspective}

Volume 3 Issue 1

Received Date: January 08, 2020

Published Date: January 23, 2020

DOI: $10.23880 /$ phij-16000135

\section{Abstract}

In philosophical terms, stupidity may be viewed as a three way compromise among: 1.) "Pragmatic rationality"- how well individuals maximize the satisfaction of their desires, given their schemas; 2.) "Epistemic rationality"-the internal consistency of the schemas; and 3.) "Theoretical rationality- how well the schemas represents the external world ${ }^{1}$. All this would be much easier $^{2}$ for cognitive theorists ${ }^{3}$ to understand and accept were it not for the schematic legacy of the Age of Reason.

In the eighteenth century, people sought to understand their world and achieve an accurate and internally consistent picture of its complexities. Rationalists thought that people, like Newton, dealt with reality in an analytical, reasonable manner, with emotions under the direction of cognitive factors ${ }^{4}$ and, for example, on the political front in democracies, cast an informed vote according to their best interest after having studied the relevant issues ${ }^{5}$. Although there are very few sworn rationalists left, due to the fact that people so frequently deviate from the norms of reason ${ }^{6}$ (e.g., voting irrationally according to emotions or appearances), many students of human behavior are still enthralled by the assumption that people are reasonable ${ }^{a}$ and wise-as in Homo "sapiens", meaning wise.

Confusion as to the relationship of wisdom ${ }^{8}$ to knowledge has likewise impeded our understanding of ourselves for years, proving the self-confirming point that while we are a learned animal, we are appallingly slow learners. Ironically, the greatest obstacle to our learning has not been genetic or physiological but the stock of accumulated illusions (aka "Knowledge") we have created for ourselves. Evasions, suppressions, and lies have created a missive store of misinformation'. Put another way, Rousseau observed that "Our minds have been corrupted in proportion" to the improvement of human knowledge ${ }^{10}$. That is, the better our

a These being psychology's equivalent of geography's "Flat-earthers": see Fishbein and Ajzen for an astounding, recent example. knowledge, the more it defines/confines us.

Two hundred years ago, rationalists believed that as we learned more about our world we would become wiser. That belief is no longer tenable. Knowledge accumulates; wisdom does not. For all our vaunted skills in communication, we still learn pretty much as do rats, with little wisdom (i.e., not intellect ${ }^{11}$ ) passed on from one generation to the next and even less developed by public schools- which are tasked with passing on superstitions, taboos and condoms ${ }^{12}$. Worse yet, each generation finds a new way to mess itself up because we do not behave even like knowledgeable rats. As knowledge accumulates, so do misconceptions, old wives' tales and idiotic ideas and beliefs of all sorts ${ }^{13}$ as well. These do as much to shape our behavior as do immediate circumstances, since it is through our cognitive world that the stimuli we perceive are interpreted, evaluated and accepted as the basis for our behavior.

The rationalists could not comprehend the nature of stupidity, intelligence or humanity because they viewed the universe as a Manichaen expression of ideals in logical conflict with their opposites -good vs. evil, God vs. the Devil, etc. They did not perceive healthy behavior as a balance or blending of social needs with environmental conditions and group goals with syntactic limits. Rationalists did posit a superegoish ideal personality which would presumably provide a perfect fit for an individual into a perfectly smug 


\section{Philosophy International Journal}

society ${ }^{14}$ in heaven. However, they failed to appreciate how wasteful it was to divine philosophical systems which were internally consistent but functionally useless because they existed only in splendid, cerebral isolation.

In fact, it was exactly such effete thinking that characterized the unenlightened Germanic revival of the ancient Greek tradition of impractical philosophy in the eighteenth century. In that age, when prevailing Christian values were being challenged if not undermined, France ruled the land, England ruled the seas and Germany ruled the air ${ }^{15}$, The Teutonic schemas, so beautiful in their logical consistency, did not relate to anything real, and as Kant ${ }^{b}$ never quite got around to pointing out, there are really only two good, valid criticisms of pure reason - one is that it is pure; the other is that it is reasonable.

A corollary of Kant's rationalism was a naive moralism smacking of Socratic idiocy. His "Categorical imperative" is really a good old Germanic Golden Rule ${ }^{16}$ rather than the new version-that he who has the gold rules. The assumption is purity of intent with all conflicts resolvable by good-faith reasoning while bad-faith reasoners would come around under the influence of patient coaxing of good natured negotiators. This attitude was alive if feeble in the late 1970's as evinced by President Jimmy Carter in his benign approach to military matters when dealing with the hardnosed Russians

\section{Bibliography}

1 Harman G (1995) Rationality. In: Smith E, Osherson D (Eds.) Thinking, Cambridge University Press, Cambridge, England, 3: 32-58.

b Kant's neo-Parmenidesic/Humesque saw that we really cannot know anything about reality is demolished by our proven ability to predict tides, eclipses and day length, i.a., How do we do that if we know nothing? Better yet was the discovery of Neptune in 1846 made possible by calculations derived from perturbations of Uranus. (Evans. p. 388.)

More to the point, Kant maintained that by the time a person can reason, s/ he has picked up values which taint verbal thought processes so attendant reasoning is not really pure: i.e., it is shaped by the defining linguistic schema. Kant would have undoubtedly been uncomfortable with the organization of the brain of social man as a function of primal human reaction and sacrifice to the furies of fanaticism and paranoia. (A Miller.) which repeat themselves in various forms in culture after culture throughout history. The wrinkle offered here is that the structure is learned as the schema is formed by the normal process of linguistic aculturation- not inherent in organic brain structure as Kant had it. (Rooney. 42.)
2 Boorstin D (1998) The Seekers. Vintage, NY, pp: 155.

3 Anderson J (1990) The Adaptive Character of Thought. Erlbaum, Hillsdale, NJ.

4 Proshansky H, Seidenberg B (1965) Basic Studies in Social Psychology. Holt, Rinehart and Winston; New York. Welles J (1988) Societal roles in self-deception. In: Lockard J, Paulhus P (Eds.), Self-deception: An Adaptive Mechanism? Prentice Hall, Englewood Cliffs, NJ, pp: 56-59.

5 Watson R (2010) While fear and paranoia take control of rational voters. Sun-Sentinel; Fort Lauderdale, FL. 5F.

6 Stanovich K (2002) Rationality, intelligence, and levels of analysis in cognitive science: Is dysrationalia possible? In: Sternberg R (Ed.), Why Smart People Can Be So Stupid. Yale University Press, New Haven, CT, pp: 125.

7 Harari Y (2015) Sapiens. Harper, New York.

8 Austin E, Deary J (2002) Personality Dispositions. In: Sternberg R (Ed.), Why Smart People Can Be So Stupid. Yale University Press; New Haven, CT, pp: 191.

9 Mishra P (2017) Age of Anger. Ferrar, Straus and Giroux, New York, pp: 48.

10 Ibid. p. 89.

11 Sowell T (2009) Intellectuals and Society. Basic Books, New York. 1.

12 Woods T (2007) 33 Questions About American History. Three Rivers Press, New York, pp: 261.

13 Pitkin W (1932) A Short Introduction to the History of Human Stupidity. Simon and Schuster, New York, pp: 165.

14 Hall C, Lindzey G (1970) Theories of Personality. Wiley, New York.

15 Richter P (1861) Of Mme. de Stael's Germany. New York, pp: 51.

16 Hodgkinson T, vd Bergh $\mathrm{H}$ (2015) How to Sound Cultured. Publishers Group West, Berkeley, CA, pp: 138. 